\title{
A teoria econômica dos Estados antigos A questão do capitalismo na Antiguidade na visão de Weber
}

Jürgen Deininger

Tradução de Paulo Astor Soethe

\section{Observações preliminares}

"Capitalismo" e "Antiguidade": uma questão fértil e esclarecedora? O que as duas coisas têm a ver uma com a outra? Uma delas, o capitalismo, como economia aquisitiva privada, e sobretudo após o colapso da assim chamada economia "socialista" planificada, volta hoje a ser amplamente considerado como o melhor e mais exitoso sistema econômico, em especial da modernidade, depois de haver se retraído - por longo tempo, e não sem forte influência ideológica -, por exemplo, na Alemanha, e se mantido por detrás da designação "economia social de mercado". A outra, a Antiguidade, não obstante todas as suas realizaçôes culturais, em clara oposição a isso, aparece como um sistema social distante, "escravagista", sustentado economicamente em grande medida pelo trabalho de cativos... Haveria muito a dizer sobre os vários outros elementos ideológicos que atuaram sobre os dois conceitos, capitalismo e Antiguidade. Deve-se chamar a atenção aqui, no entanto, sobretudo para o fato de que o conceito "capitalismo" nos dias atuais parece ser empregado mais uma vez de modo reconhecidamente imparcial, o que talvez indique que também de um ponto de vista histórico haja uma abertura maior para o que possa receber o nome de "capitalismo". E, com isso, um interesse renovado também pela pergunta sobre a existência e a significação do capitalismo já na Antiguidade. 
De uma perspectiva totalmente diversa, ainda se poderiam a limine impor restrições de fundamento ao emprego do conceito "capitalismo" como uma forma econômica no essencial já existente na Antiguidade. Trata-se - até certo ponto - do argumento "filológico" de que nem a palavra, nem o conceito são próprios à Antiguidade, mas tão somente posteriores a ela, e portanto estranhos à consciência antiga. Em todo caso, "dinheiro" e "capital", por exemplo, não são a mesma coisa, e "dinheiro" não tem nas línguas antigas a nuance especial que se atribui a "capital" como meio planejado para a obtenção de ganho próprio por meio da produção e da circulação de bens. Mesmo o termo grego $c h r^{-}$ematismós, o anseio ilimitado por dinheiro ( $\mathrm{chr}^{-}$ema $)$, não abarca a noção específica de formação de "capital", acumulação de "capital", "capital” investido etc. Nesse sentido, "capitalismo" na Antiguidade é, sem dúvida, um capitalismo avant la lettre, o que entretanto não significa, de modo algum, algo extraordinário, tampouco um argumento contra a designação como tal - ao menos enquanto se possa comprovar a coisa designada, em todo caso. Afinal, as línguas antigas também não conhecem, por exemplo, conceitos gerais para "economia" ou "sociedade", sem que a presença de ambos tenha sido seriamente colocada em questão. Não se pode ignorar aqui o fato de que a formação do conceito no pensamento político antigo era notadamente mais desenvolvida que a do pensamento econômico, o que ainda hoje se revela com a multiplicidade de conceitos de origem grega e latina para fenômenos políticos fundamentais, desde a própria "política” até "democracia”, desde "república" até "ditadura”. Não há conceitos econômicos comparáveis, apesar do termo grego oikonomia (que na verdade quer dizer "administração doméstica"), que sob esse aspecto constitui antes uma exceção. Significativamente ocorre, em contraposição (também em vista da imagem de Max Weber da economia antiga $)^{1}$, que a terminologia dos bancos e do comércio - em muitos casos, e não por acaso - remonta não à Antiguidade, mas à Idade Média tardia na Itália.

Em tal medida não poderia haver restrição alguma, ao menos "filológica”, ao emprego do conceito "capitalismo" - surgido somente pouco antes da metade do século XIX na França - para designar formas econômicas estruturalmente correspondentes já existentes na Antiguidade. A questão central, no entanto, continua sendo naturalmente a da adequação objetiva, ou seja:

2. Para um panorama bem conciso (com indicaçōes bibliográficas), do ponto de vista da história da ciência, ver Cartledge (1996, pp. 287 ss.). verificam-se de fato formas econômicas similares e comparáveis na Antiguidade? E em que medida? Embora não se possa dizer que a questão não tenha sido tratada diversas vezes ${ }^{2}$, não seria menos correto afirmar que até hoje praticamente ninguém se ocupou de maneira tão acurada do problema em 
seu todo quanto Max Weber, e isso de modo mais aprofundado no capítulo introdutório da terceira (e última) versão de seu texto "Agrarverhältnisse im Altertum" [Relações agrárias na Antiguidade], intitulado "Sobre a teoria econômica do mundo dos Estados antigos", publicado em 1908 no Handwörterbuch der Staatswissenschaften [Dicionário das ciências do Estado] ${ }^{3}$.

\section{"Capitalismo", "capital" e compósitos na Antiguidade, segundo Max Weber,} antes das "Relações agrárias" de 1908

O capítulo introdutório de 1908 não representa o primeiro texto em que Weber chegou a falar da significação do capital na Antiguidade. Mais que isso, ele desde o início empregou recorrentemente conceitos como capital e seus compósitos para a economia da Antiguidade. Isso vale tanto para a Römische Agrargeschichte [História agrária romana] como para seus respectivos cursos, que hoje se conhecem melhor graças à MWG, e para as duas primeiras versões de "Relações agrárias na Antiguidade" (cf. MWG I/6, pp. 146-227).

Primeiramente, no que diz respeito à História agrária romana, de $1891^{4}$ - o ponto de partida e fundamento de todas as confrontaçóes posteriores de Weber com a história econômica e social da Antiguidade -, merece atenção de início sobretudo o trecho em que Max Weber fala pela primeira vez em "capitalismo" na Antiguidade, ao discutir a permissão dada aos cidadãos romanos para as mal-afamadas ocupações privadas no ager publicus, isto é, na "terra pública” que se tornou propriedade estatal em decorrência das conquistas romanas (cf. MWG I/2, p. 73). Theodor Mommsen já havia se manifestado de maneira muito crítica em sua Römische Geschichte [História romana], no contexto dessas ocupaçôes, sobre a aparição dos "capitalistas", aos quais se havia oferecido aqui um "terreno para especulação rentável e isenta de qualquer esforço ou risco" (Mommsen, 1887, p. 267). Na História agrária romana de Max Weber, no capítulo sobre a "terra pública e taxável”, um dos subitens dedicados às ocupações tem explicitamente o título "Capitalismo agrário" (cf. MWG I/2, pp. 73 ss.). Com vista à admissão do cidadão para a "livre ocupação" do solo na terra pública ou obtida por meio de conquistas, Max Weber falou aqui do "capitalismo mais irrefreado nas regiōes agrárias, do qual jamais se ouviu falar na história”, pois nessas ocupações a livre concorrência só veio em favor dos "grandes capitalistas, tanto patrícios como plebeus" (Idem, ibidem $)^{5}$. Para Weber, essa "luta de classes pelo ager publicus" se
3. O verbete do dicionário está agora em MWG I/6, pp. 320747; doravante, somente com a indicação do número de página, citado na edição de Weber (1988, pp. 1-288).

4. Citado a seguir de acordo com a ediçãa MWG I/2.

5. Cabe atentar para a crítica dura, feita logo a seguir, contra a "indecência" da atividade dos "grandes capitalistas" (MWG I/2, p. 73). 
6. Ver as indicações de trechos em MWG I/2, p. 234 (índice remissivo). Weber (p. 90) constata "a tendência capitalista inaudita dessa legislação” (a saber: a Lei Agrária de 111 a.C.).

7. Ver também "Formação do capital”, MWG III/5, p. 99.

8. Também de acordo com a terceira versão de 1908 , foi um "capitalismo agrário inaudito" (grifo de Weber) que se impôs com as ocupaçôes (cf. MWG I/6, p. 233). Para uma exposição detalhada, ver idem, pp. 231-233; sobre a questão da datação da Lei Licínia, ver idem, p. 232.

9. Ver MWG III/1, pp. 413, 425 (textos 1 e 2), 436; ver também pp. 426, 429, 425. No entanto, em vez de "economia capitalista de oikoi", Weber escreveu "economia capitalista de plantações", ou algo similar (p. 427).

10. Aqui não será tratada, em maiores detalhes, a conferência "Die sozialen Gründe des Untergangs der antiken Kultur" [As causas sociais do declínio da cultura antiga], de 1896, onde Weber (provavelmente por causa do caráter "popular" da conferência) renunciou ao emprego do conceito "capital" e derivados; ver Weber, 1988, pp. 289-311 (também MWG I/6, pp. 82-127). estende desde o tempo que se segue à Lei das Doze Tábuas até o fim da República; nesse contexto, a tentativa de uma fixação de limites máximos de ocupação para cada indivíduo, pela Lei Licínia, ainda datada por Weber em 367 a.C., teria sido uma primeira reação contra o capitalismo agrário (cf. Idem, pp. 74 ss.).

Além disso, não faltam na História agrária romana conceitos como "capital”, "capitalistas" (como substantivo e adjetivo), "grandes capitalistas", "capital de investimento", "formação de capital" e "investimentos de capital" ${ }^{6}$, sem que Weber, notadamente, tenha considerado necessária uma fundamentação mais detida desses conceitos.

Mesmo mais tarde, Weber sempre sustentou essa sua avaliação específica das ocupações no ager publicus como "capitalismo agrário". Assim, nas notas de seu curso ministrado entre 1894 e intitulado "Direito agrário e história agrária", também se encontra, no mesmo contexto, o conceito "capitalismo agr[ário]" (cf. MWG III/5, p. 90) 7 . O mesmo ocorre em todas as três versóes de "Relaçôes agrárias na Antiguidade”, de 1897, 1898 e 1908: Weber constata em contextos equivalentes, a cada vez, um “capitalismo agrário inaudito" em Roma (cf. MWG I/6, p. 204) ${ }^{8}$. Em seu curso principal de economia política, ministrado seis vezes entre 1894 e 1896, intitulado "Economia política geral ('teórica')", encontram-se na seção "O desenvolvimento econômico na Antiguidade" observações sobre a época de "desenvolvimento capitalista crescente" nas diversas cidades-estados, sobre um "capitalismo desmedido em território agrário" e sobre o "capitalismo" dos proprietários de escravos e rebanhos (também aqui no contexto das ocupações no ager publicus), como também sobre a "escravaria capitalista" . Os numerosos outros exemplos nessas notas de aula sobre "capital", "capitalistas" (como substantivo e adjetivo) etc. não serão aqui indicados. Da mesma forma, em relação à Antiguidade (portanto, nas duas primeiras versões de "Relações agrárias", Grécia e Roma, e na terceira também a Mesopotâmia), Weber empregou reiteradamente conceitos como "capital" e "capitalista", também aqui sem qualquer tentativa de explicação mais detalhada desses conceitos (cf. Idem, pp. $167,191,204)^{10}$.

Merece atenção especial uma passagem que se encontra logo no início de História agrária romana. Ali se fala da "colossal encenação da política de conquistas romanas no continente", que "significou não apenas uma ampliação da posição de poder político da cidade, mas também um aumento constante da área submetida aos assentamentos romanos e à exploração capitalista" (MWG I/2, p. 3). Na ligação imediata de "posição de poder político" 
e "exploração capitalista” talvez já se possa reconhecer até mesmo in nuce a teoria weberiana do capitalismo especificamente "político" da Antiguidade, que se desenvolverá mais tarde em $1908^{11}$.

\section{A problematização do conceito de capitalismo antigo por Max Weber em "Relações agrárias na Antiguidade", de 1908}

Assim, desde a História agrária romana Weber sempre chamou diversas vezes a atenção para elementos manifestamente "capitalistas", sobretudo na Roma da fase tardia da República e na fase inicial do Império, sem dar quaisquer explicações mais detalhadas a respeito. Mais tarde, ele mesmo comentou que originalmente (ou seja, antes da última versão de "Relaçôes agrárias") só tinha se disposto a designar algumas "manifestações isoladas" da economia antiga como "capitalistas" e por isso tinha evitado falar em "capitalismo antigo". Mais tarde, como demonstra a última versão de "Relações agrárias", ele alteraria sua terminologia (cf. Weber, 2004a, pp. 360 ss. e 373, nota 32) ${ }^{12}$. Que isso tenha realmente ocorrido e que Weber só então tenha realizado um estudo detalhado sobre a natureza e o papel do capitalismo na Antiguidade revela sem dúvida o fato de que, para ele, o problema do capitalismo ganhou considerável importância quando escreveu, em 1907-1908, uma nova e abrangente versão de "Relações agrárias" para a nova terceira edição do Dicionário das ciências do Estado. Pouco antes havia saído a obra de Werner Sombart sobre o capitalismo "moderno", fundamental e muito influente (cf. Sombart, 1902). Já antes, em uma resenha de História agrária romana, Sombart havia sido veemente ao rejeitar o uso que Max Weber fizera do conceito "capitalista” referido à Antiguidade e fundamentou sua posição com o argumento da falta de um "quadro de trabalhadores livres e proletários" na Antiguidade ${ }^{13}$. A isso somou-se então naturalmente o grande texto de Weber sobre a ética protestante e o espírito do capitalismo, de 1905-1906, que o conduziu a um aprofundamento de sua própria visão do capitalismo e decerto corroborou, não obstante todos os aspectos diferentes, o emprego do conceito também para a Antiguidade. A observação explícita na "Ética protestante", segundo a qual ali se tinha em vista, como espírito do capitalismo, "naturalmente" apenas o do capitalismo moderno, europeu ocidental e americano, e não por exemplo o do capitalismo da Antiguidade, completamente distinto daquele e carente de um éthos correspondente - essa observação Weber acrescentou somente em sua redação do texto de 1920
11. Ver infra.

12. Sobre o conceito de "capitalismo" na Antiguidade em Weber, no período anterior a 1908 , ver supra.

13. A resenha de Sombart encontra-se em Zeitschrift für Social-und Wirtschaftsgeschichte 1 , 1893 , p. 353 . Sobre a posição de Weber, ver ao longo deste artigo. 
14. No texto original de 1905 1906 não se encontra essa passagem.

15. Sobre o ano de publicação "1908" (que se favoreceu aqui em detrimento do usual "1909”), ver o texto de Deininger em MWG I/6, p. 305.

16. Ver MWG I/6, pp. 758-765, com remissōes a exposições correspondentes e detalhadas na versão de "Relaçōes agrárias" de 1908. Aqui, no entanto, Weber aborda o "capitalismo" mais de perto somente no contexto da época imperial romana (cf. Idem, pp. 764 ss.).

17. Assim, o capítulo sobre o Egito foi subdividido em "Antigo" (мwG I/6, pp. 62-70), "Médio" (pp. 70-72) e "Novo Império" (pp. 72-83), ao passo que o capítulo sobre a "Hélade" aparece dividido em "Época préclássica" (pp. 93-128) e "Época clássica (em especial: Atenas)" (pp. 128-154). O capítulo sobre Roma abrange as seçôes "A cidade-estado" (pp. 190-227), “O período de expansão de Roma” (pp. 227-253) e ainda "Fundamentos do desenvolvimento na época imperial" (pp. 253-278). 18. Ver supra. (cf. Weber, 2004b, p. 77) ${ }^{14}$. Contudo, já em 1910 manifestou que teria "sido naturalmente sábio", na "Ética protestante", ao falar expressamente a cada vez do "capitalismo moderno" (Idem, pp. 361 e 364, nota 34).

A análise detalhada desse "capitalismo" antigo representou claramente o verdadeiro centro da terceira versão de "Relações agrárias na Antiguidade", de 1908 - enormemente ampliada, em comparação às versôes de 1897 e $1898^{15}$. Isso também se depreende da conferência de duas horas intitulada "Capitalismo na Antiguidade”, realizada por Max Weber para o Círculo de Eranos, em Heidelberg, em fevereiro de 1908, logo após a conclusão definitiva de "Relações agrárias", da qual só se conservou um curto resumo de próprio punho e que, em face do texto impresso de "Relações agrárias", não traz objetivamente nada de novo - mas confirma a importância dessa questão fundamental para o artigo do Handwörterbuch der Staatswissenschaften, completamente retrabalhado (cf. MWG I/6, pp. 748-753). Além disso, cabe ainda mencionar o curto artigo de Weber, também de fevereiro de 1908, "Agrargeschichte, Altertum" [História agrária, Antiguidade], escrito para a enciclopédia Religion in Geschichte und Gegenwart [Religião na história e no presente $]^{16}$.

Se a primeira versão só havia tratado da Grécia e de Roma, e a segunda fora acrescida de algumas seçôes relativamente curtas sobre o Egito e a Mesopotâmia (cf. MWG I/6, pp. 150-169), a última versão foi expandida por Weber de maneira extraordinária sob três aspectos. De uma parte, acrescentaram-se, com Israel e o helenismo (cf. Idem, pp. 83-93 e 154-190), dois domínios novos, jamais tratados até então; de outra parte, os territórios já estudados, ou seja, a Mesopotâmia, o Egito, a "Hélade” e Roma, sofreram todos uma ampliação considerável, o que também se refletiu no aumento das subdivisões ${ }^{17}$. Em terceiro lugar, por fim, Weber sumarizou os territórios individuais tratados em um longo capítulo intitulado "A história agrária dos principais territórios da cultura antiga" (cf. Idem, pp. 45-278), ao qual ele antepôs algo também novo em relação às versões anteriores, a saber: uma reflexão introdutória e explícita com o título "Sobre a teoria econômica do mundo dos Estados antigos" 18 .

Sobre a problematização

Como neste contexto não entra em cogitação uma confrontação detalhada com as considerações extremamente amplas de Max Weber, capítulo a capítulo, sobre os principais territórios da "cultura antiga", cabe atentar 
em primeira linha, com mais detalhes, ao capítulo introdutório "teórico". Ele parece especialmente importante ao menos sob dois aspectos: primeiro, para a questão central ora proposta acerca do "capitalismo" da Antiguidade segundo Max Weber, suas peculiaridades e limites; mas também na medida em que o aparato conceitual histórico e teórico nele desenvolvido se mostra decisivo para a última versão de "Relações agrárias" em seu todo. Contudo, embora essa visão de conjunto se oriente em primeiríssima linha pelo capítulo teórico de "Relaçóes agrárias" de 1908, talvez fosse apropriado retomar também as consideraçóes sobre questôes específicas na parte principal do artigo, mais detalhada. É preciso adiantar, porém, que não se pode tratar aqui da história da questão do "capitalismo na Antiguidade", que não chegou de modo algum ao seu fim e ainda continua; e também que só se pode pinçar uma seleção de questôes importantes em meio à estonteante profusão de ideias da concepção weberiana do capitalismo na Antiguidade. Isso ocorre na esperança de que se evidenciem, assim, alguns dos aspectos capitais das ideias de Weber sobre o assunto. Tampouco é possível, nesse contexto, uma confrontação com as apresentações do capitalismo antigo na ampla bibliografia mais recente sobre Weber ${ }^{19}$. De modo algum, porém, se pode adentrar na questão de se a imagem de Weber do capitalismo da Antiguidade simplesmente é, in toto, "correta" ou não ${ }^{20}$. Mais essencial deveria ser o esforço de obter clareza quanto ao tipo de perguntas produtivas a que Weber, a todo momento, busca conduzir o leitor.

\section{O enquadramento de "Relações agrárias na Antiguidade" de 1908:} o nexo cultural dos faraós até o presente

Tratemos então de "Relações agrárias", que Max Weber publicou em 1908. Segundo uma observação ao fim do artigo, Weber compreende o presente como parte de um continuum histórico abrangente que se estende "dos faraós até a nossa cultura" (cf. MWG I/6, p. 264) 21. Para Weber esse continuum compõe-se, por sua vez, de dois grandes complexos, a saber: da época que vai desde o início das grandes culturas orientais antigas até o fim do Império romano (ou da Antiguidade) ${ }^{22}$, e da cultura medieval e da Época Moderna, que depois se desenvolveu até o presente. Já por essa razão parece justificado considerar fenômenos culturais como o "capitalismo" no quadro de uma continuidade de amplo alcance. Entre as principais diferenças da Antiguidade em relação à Idade Média/Época Moderna inclui-se, para Max Weber, especialmente o centro de gravidade do cenário
19. Cabe mencionar, entre os títulos, sobretudo duas obras: Colognesi (2004), com ênfase na interpretação de Weber e destaque das novas abordagens em seu pensamento sobre a Antiguidade; além disso, Love (1991), com tentativas de uma aproximação em parte crítica a Weber.

20. Sobre a insegurança da pesquisa atual quanto a essa questão, ver também, por exemplo, além de Cartledge (1996, pp. 287 ss.), Harris et al. (2007, pp. 528 ss.). Para algumas indicaçôes relacionadas com a discussão sobre o "capitalismo" antigo por contemporâneos de Weber, ver o texto de Deininger em MWG I/6, pp. 38-40.

21. Enquanto em MWG I/6, p. 278, Weber fala do "continuum do desenvolvimento cultural medievaleuropeu”.

22. O Império romano como "encerramento da Antiguidade" (Weber, 1988, p. 43). Sobre isso ver Deininger em MWG I/6, pp. 37-55. 
23. Sobre o que segue, ver especialmente Weber (1988, pp. 7-12). Textos importantes sobre o assunto em Finley (1979). dos dois domínios culturais: no caso da Antiguidade, as culturas de "margem de rio" junto ao Eufrates, ao Tigre e ao Nilo, ou então, mais tarde, as "culturas costeiras" no mar Mediterrâneo, ao passo que a cultura medievalmoderna tem seu centro de gravidade no “interior" europeu. Para Weber, o deslocamento do centro de gravidade econômico, cultural e político das costas mediterrâneas para o interior representa, de maneira geral, uma das cesuras mais decisivas e mais ricas em efeitos no desenvolvimento cultural ocidental, a cujas consequências de grande alcance para a história econômica ele retornará muitas vezes. Mas não apenas o cenário estava entre as "particularidades específicas" da cultura antiga, responsáveis pelas "diferenças agudas” em face da Idade Média e da Época Moderna (cf. Weber, 1988, p. 4). Diferenças essenciais revelam-se também na intensidade do comércio, muito maior já na Idade Média tardia, e na falta do "proletariado" moderno como portador da produção na Antiguidade (cf. Idem, p. 6), bem como no papel importante da escravidão, justamente no "florescimento clássico das comunidades 'livres' " da Antiguidade. Dessas divergências decorre para Weber, em primeiro lugar, a questão de se a utilização das mesmas "categorias" seria permitida, tal como empregadas na história econômica medieval e, de modo pleno, na história econômica moderna. Para esse problema fundamental, um marco na história econômica antiga e conhecido posteriormente como "controvérsia de Meyer-Bücher", Weber cita três concepções distintas da história econômica da Antiguidade, tal como representadas por Johann Karl Rodbertus (1805-1875), Karl Bücher (1847-1930) e Eduard Meyer $(1855-1930)^{23}$.

0 debate sobre os fundamentos da economia antiga: Max Weber e a "controvérsia de Meyer-Bücher" nas "Relações agrárias" de 1908

Com o nome Rodbertus relaciona-se em primeira linha o destaque do oikos e sua constituição como particularidade decisiva da economia antiga. Em continuidade sobretudo com Aristóteles, ele entendia como a particularidade mais importante da economia antiga a predominância da "economia doméstica fechada", ou seja, da produção própria da "casa” (oikos), ampliada pelo trabalho escravo, diante da qual o comércio não passava, na Antiguidade, tão somente de uma espécie de fenômeno secundário ou ocasional. Já em História agrária romana, Weber havia elogiado expressamente a "exposição muito sugestiva" na qual Rodbertus havia remetido "todo o curso da história econômica da Antiguidade" à autarquia do oikos. Ao mesmo tempo, porém, 
interpôs a crítica de que o oikos autárquico (ao menos em Roma) não teria representado o começo do desenvolvimento (que Weber antes situava, em Roma, nas "comunidades que compartilham o terreno"); ao contrário, o oikos só teria existido no período tardio de Roma, em consequência do retrocesso da economia de circulação e do surgimento das "dominações fundiárias", e seria, portanto, "nas propriedades fundiárias rurais, no essencial, não mais que um produto tardio do desenvolvimento" (MWG I/2, p. 137). A visão excessivamente parcial de Rodbertus da importância dominante do oikos autárquico para a economia antiga como um todo, para sua "oiko-nomia" (caso se queira chamá-la assim), acabou não tendo grande ressonância na ciência histórica. Não obstante, a teoria do oikos foi assumida pelo filólogo clássico e economista político Karl Bücher, que, de acordo com Weber, defendeu que a teoria do oikos não fora marcante para a Antiguidade como um todo, mas que deveria ser considerada uma "construção ideal-típica". Ela também implicava, entretanto, uma "restrição muito forte, e plena de consequências, do fenômeno da circulação" (Weber, 1988, p. 8), sendo uma delas o "rebaixamento" social e econômico das camadas que, do contrário, poderiam ter dado suporte a esse "fenômeno da circulação", a saber: os empreendedores industriais, ou seja, artesãos e comerciantes (cf. Idem, ibidem). Aqui já ecoa a tese de Max Weber do centro de gravidade agrário do capitalismo antigo, em oposição ao caráter mais fortemente industrial do capitalismo medieval e moderno ${ }^{24}$.

No entanto, não demorou muito a que também Bücher se deparasse com uma rejeição veemente "dos historiadores", que recebeu sua articulação mais decisiva em 1895, na conferência programática de Eduard Meyer intitulada "Die wirtschaftliche Entwicklung des Altertums" [O desenvolvimento econômico da Antiguidade]. Meyer repudiou enfaticamente todas as categorias da história econômica específicas para a Antiguidade, o que, para Weber, se revelava por exemplo no emprego que Meyer fazia de conceitos como "fábrica" e "trabalhador fabril" ou, mais ainda, em uma formulação como a que dizia não ser possível imaginar "quão modernas" eram as relações econômicas na Atenas dos séculos v e IV a.C. (cf. Idem, ibidem). De fato, escreveu Max Weber, não se podia constatar em Atenas, ou onde quer que fosse, a presença de "fábricas" no sentido econômico de "organização diferenciada do trabalho" (Idem, p. 9) 25 . O simples ergasterion industrial (a "oficina”), que talvez pudesse entrar em questão aqui, era algo completamente diverso. Weber enumera, então, uma série de exemplos de um desenvolvimento consideravelmente menor do comércio na Antiguidade, em comparação com
24. Ver infra.

25. Sobre isso, ver também Weber (1988, pp. 20 ss., 32 ss.). 
a Idade Média, e de suas formas de negócios, assim como da área bancária e das finanças públicas (cf. Idem, p. 10). Ao mesmo tempo, Weber também indica que o oikos, no sentido de Rodbertus, havia "desempenhado um papel altamente significativo na economia da Antiguidade", em especial e sobretudo na fase inicial ainda marcada por uma economia natural, sobretudo no Oriente, bem como na fase tardia da Antiguidade greco-romana, que novamente se aproximou da economia natural (cf. Idem, ibidem). Por outro lado, as "grandes escravarias" do período "clássico", portanto da Grécia e de Roma, deveriam ser diferentemente avaliadas, pois nada tinham a ver com a economia autárquica dos oikoi. Isso sem considerar a importância dos diversos tipos de trabalho livre que, na avaliação de Weber, teriam sido subestimados (cf. Idem, p. 11). Essa importância, contudo, é limitada pelo próprio Weber, ao destacar o "grau de organização" bem mais baixo do artesanato livre na Antiguidade, em comparação com a Idade Média (cf. Idem, p. 12).

Se justamente na época "clássica" da Antiguidade a economia do oikos tendia a desaparecer em várias partes e o trabalho livre ganhava maior significação, então se coloca para Weber a questão de se a Antiguidade teria conhecido uma "economia capitalista em uma medida relevante, do ponto de vista da história cultural" (Idem, ibidem). Embora as cidades antigas (entre outras) tenham sido muito mais centros de consumo que de produção, a circulação de bens e os ganhos desempenharam um papel cada vez maior, como indica a indústria de exportação desenvolvida nas cidades, a dependência considerável da importação de cereais e a compra de escravos, bem como o papel que interesses comerciais específicos desempenhavam na política. Com isso, colocava-se a questão de se, nesses casos, se tratava de épocas com uma "estrutura capitalista" (Idem, p. 13).

\section{0 "capitalismo" da Antiguidade na definição de Max Weber}

Em busca de respostas claras, Weber se volta em primeiro lugar para uma definição formal do conceito de "capitalismo" (Idem, pp. 13-16). De saída ele constata que sob "capital" deve-se entender em princípio o "capital econômico privado aquisitivo"; "bens, portanto, que estão a serviço da obtenção de 'ganho' na circulação de bens" (Idem, p. 13). Decididamente, Weber refuta uma das principais objeçôes contra a existência de uma economia aquisitiva capitalista na Antiguidade: a ideia de que "capitalismo" pressupóe fundamentalmente a existência de trabalhadores livres e que seria por princípio incompatível com a escravidão. Para Weber, não haveria razão 
para restringir esse conceito, por qualquer motivo, a um tipo determinado de valorização do capital, qual seja a "exploração de trabalho alheio por meio de contrato com o trabalhador 'livre' ", e com isso atribuir-lhe características sociais. Ao contrário, "capitalismo" seria um conceito puramente econômico e legitimado por toda a parte "onde objetos de posse, que são objetos de circulação, são utilizados por particulares com a finalidade de aquisição na economia de circulação". Mas, se é assim, então não haveria "nada mais seguro do que uma modelagem 'capitalista' verdadeiramente ampla de épocas inteiras da história antiga - e justamente das 'mais grandiosas' ", com o que se tem em mente sobretudo a Atenas "clássica” e a Roma da República tardia (cf. Idem, pp. 15 ss.).

\section{O capitalismo na Antiguidade: particularidades gerais}

A partir desse ponto, importam a Weber, inicialmente, características básicas gerais do capitalismo antigo, antes de se voltar a momentos singulares importantes. Depois da rejeição veemente da afirmação de Eduard Meyer, segundo a qual não se poderia imaginar "quão modernas" eram as estruturas econômicas da Atenas clássica (cf. Idem, p. 8), talvez parecesse surpreendente, por um momento, que a economia ateniense da época clássica apresentasse uma marca notadamente "capitalista". Contudo, é claro para Weber que o capitalismo da Antiguidade não era um capitalismo "moderno", mas distinguia-se fundamentalmente deste em pontos importantes. Antes de mais nada, em dois deles: por um lado, o caráter econômico do capital, na medida em que faltavam ao capital todos os modernos meios técnicos de produção (cf. Idem, p. 16); por outro, o fato já mencionado de que, para o capitalismo, os cativos, ou escravos, desempenhavam um papel constitutivo na vida econômica. Diversas manifestaçôes de Weber a respeito deixam claro que ele não alimentava ilusôes quanto às condições de vida dos escravos ou do "capital de escravaria" no capitalismo da Antiguidade ${ }^{26}$.

Em relação às possibilidades de aplicação mais importantes para o capital privado na Antiguidade, Weber destaca sobretudo o arrendamento estatal (arrendamento latifundiário), bem como o arrendamento de impostos como "coroamento" das formas de valorização do capital na Antiguidade (cf. Idem, p. 29) $)^{27}$, e menciona ainda nesse contexto (sem que se possam aprofundar aqui esses aspectos) a mineração, o comércio marítimo, a "empresa latifundiária” agrícola (em especial de cereais, óleo e vinho), os bancos, a caução do solo, o comércio exterior e por fim, no campo industrial, a locação de
26. Ver, por exemplo, Weber (1988, pp. 18, 19, 20, 21, entre outras).

27. Weber fala das sociedades romanas de arrendamento de impostos da República tardia como os "maiores empreendimentos capitalistas da Antiguidade" (Weber, 1988, pp. 236 ss.). 
escravos para atividades artesanais e a exploração de escravos com aprendizado industrial.

As peculiaridades do capitalismo da Antiguidade: aspectos específicos

Depois desse panorama geral de traços característicos do capitalismo antigo, Weber se dedica a fatores isolados importantes que pudessem ter sido especialmente significativos para a amplitude e o tipo da economia aquisitiva capitalista na Antiguidade. Aqui se indaga pelo papel da disposição de reservas de metais nobres na velocidade de desenvolvimento de estruturas econômicas capitalistas, mas também pelas especificidades econômicas da posse de escravos “valorizados de maneira capitalista”, bem como a importância das relações políticas, em territórios específicos, para o desenvolvimento de formas econômicas capitalistas direcionadas ao ganho privado. No que diz respeito à importância dos metais nobres, Weber demonstra que não se deve superestimar o papel da disponibilidade de metais nobres (que não faltavam no Egito) para a estrutura de uma economia, seja ela capitalista ou não - independentemente de sua significação fundamental para a velocidade de um desenvolvimento capitalista (cf. Idem, pp. 10 ss., 17 ss.). Para tanto, apresentou vários exemplos, entre eles a comparação entre o Egito (marcado pelo oikos dos faraós) e a Mesopotâmia, claramente mais desenvolvida no que diz respeito à economia monetária e à circulação econômica.

Quanto às características econômicas da posse de escravos valorizada de maneira capitalista na Antiguidade, Weber investiga detalhadamente as inúmeras dificuldades ligadas ao "capital em escravos", esses "empecilhos" fundamentais, como ele reiteradamente os acentua, com que o desenvolvimento do capitalismo na Antiguidade se defrontava por toda parte. Ele designa como característicos sobretudo os altos riscos, dentre os quais se destacavam a mortalidade dos escravos, as derrotas militares e, com isso, a perda de escravos; além disso, as grandes oscilações de preços e, não menos importante, a ausência de um cálculo seguro dos custos. Este último seria também uma causa essencial da ausência (sempre destacada de maneira especial por Weber) de grandes empresas industriais (ou seja, "fábricas"), algo que era característico do capitalismo antigo e o contrapunha de modo fundamental ao capitalismo da modernidade. Ademais, uma "extração econômica do máximo lucro possível" a partir do trabalho escravo só seria possível, em última instância, na ausência efetiva da família dos escravos (cf. Idem, pp. 19 ss.). Com isso, Weber retoma a problemática das "casernas de escravos" na economia agrária romana, já 
amplamente discutida por ele em História agrária romana (com a transição posterior da economia escravista capitalista à economia da Antiguidade tardia, vinculada a glebas para colonos e pequenos arrendatários) (cf. Idem, pp. 242$248)^{28}$. Além disso, ele investiga toda uma série de outros impedimentos ao desenvolvimento de empresas grandes e duradouras, mesmo na agricultura, e chega, assim, à conclusão de que só se podia empregar escravos com ganho considerável em grandes empresas agrícolas sob a condição de que o solo fosse bom, os preços dos produtos gerados fosse alto e os escravos baratos (cf. Idem, pp. 20, 24). Não por último, Weber assinala também aqui - como em muitas outras passagens - que um "tratamento efetivamente 'capitalista' dos escravos como se fossem um meio de produção objetivo" era de forma decisiva dependente de um provimento corrente dos mercados de escravos e portanto, na prática, de guerras bem-sucedidas (cf. Idem, pp. 18-25, 29).

Particularidades políticas dos territórios específicos para o desenvolvimento de formas econômicas capitalistas na Antiguidade

Por fim, segundo Weber, a influência das relações políticas nos territórios específicos e no desenvolvimento das estruturas econômicas foi de enorme significação para o desenvolvimento do capitalismo na Antiguidade. Um papel central coube à economia financeira estatal, via de regra, a maior de todas as "empresas econômicas" na Antiguidade, que, de acordo com sua estrutura, teria substituído, fomentado ou mesmo inibido a acumulação privada de capital (cf. Idem, pp. 26-31).

Como exemplo mais marcante da substituição até certo ponto desenfreada do capital privado, Weber menciona o Egito e o amplo aparato burocrático dos faraós (cf. Idem, p. 26).

Por outro lado, certa função de determinar o ritmo da formação do capital privado pelo tipo de economia financeira existiria no caso de uma cidadeestado, sem aparato burocrático e com o auxílio de arrendatários do Estado, dispor de territórios conquistados muito grandes, como no caso da Roma republicana, onde - por causa da ausência de qualquer burocracia estatal, típica da situação das cidades-estado - o arrendamento dos impostos e da terra conquistada tivesse levado à formação de uma "classe de capitalistas privados" excessivamente influente. Tem-se em mente aqui os cavaleiros romanos que, desde Caio Graco, se tornaram um "estamento" formalizado. Sua cobiça por lucro os teria levado a apoderar-se de vultosas arrecadações romanas vindas das províncias, e sua luta com a "aristocracia administra-
28. Sobre isso, já em MWG I/2, pp. 126-158. 
29. Mais detalhadamente sobre o capitalismo em Roma, ver especialmente Weber (1988, pp. 227-253).
30. Ver infra. ["Litúrgico" (de Leiturgie) refere-se, nos escritos de Weber sobre a Antiguidade, “à obrigação, na pólis grega, dos cidadãos relativamente abonados de financiar as tarefas públicas da pólis por meio do emprego de seus próprios recursos. Especialmente no Egito ptolomaico significa em geral o vínculo estatal imediato do patrimônio privado às despesas públicas. Max Weber o emprega, ademais, como um conceito histórico geral" (MWG I/6, p. 822). Na falta de termo próprio em português, deve-se considerar esse uso terminológico de Max Weber no sentido aqui indicado. (N. E.)]

31. Ver infra.

32. Ver supra. tiva" (ou seja, o Senado) teria dominado todo o último século do período republicano. Este teria sido o auge do capitalismo antigo (cf. Idem, p. 28) ${ }^{29}$.

Um impulso inexorável para a formação de capital privado, por fim, teria sido exercido pelas finanças do Estado, sobretudo por meio da margem de ação que a "prática administrativa” de um Estado garantia ao lucro privado e que, por isso mesmo, era precipuamente menor nos Estados monárquicos que nas Repúblicas, pois o monarca não estava interessado em lucros momentâneos rápidos, mas sim na exploração de longo prazo de seus súditos e assim, ao mesmo tempo, em um tratamento que os "poupasse" (cf. Idem, p. 29). Com isso, Weber passa a tratar de uma distinção importante entre Estados republicanos e monárquicos na Antiguidade como um todo. Nos Estados monárquicos o arrendamento de impostos teria se mantido sempre sob o controle do monarca, e o "processo de controle, monopolização e burocratização" correspondente teria progredido, em todo caso, de maneira "irrefreável" em todas as "grandes" monarquias antigas (cf. Idem, p. 30). Quando cessaram as "guerras de conquista de territórios e populações" da Antiguidade e com isso o abastecimento de escravos, desapareceu também o trabalho escravo utilizável de maneira capitalista. Assim, mesmo no caso de Roma, não restou ao final o capitalismo, mas sim a "ordem burocrática”, ou seja, a monarquia ("litúrgica") 30 .

A essa vitória da ordem burocrática associou-se também, ao mesmo tempo, como Weber observa, em trecho posterior, a "aniquilação" de tudo aquilo que poderia ser denominado "liberdade" nas épocas "clássicas" da Antiguidade. Assim, o fim do desenvolvimento capitalista (ou seja, do desenvolvimento baseado na iniciativa econômica privada e na obtenção de ganho) teria sido, ao final da Antiguidade e de seu capitalismo, a "ordem" monárquica benfazeja para a massa dos "súditos"31. De outra parte, o que teria faltado como que por completo ao capitalismo da Antiguidade teria sido uma "transfiguração ética do trabalho aquisitivo", ou seja, uma "ética profissional" (cf. Idem, p. 33) ${ }^{32}$ comparável ao capitalismo dos inícios da Época Moderna, tal como Max Weber, em sua "Ética protestante", destacou como um fator essencial na história da origem do capitalismo da modernidade.

\section{"Estágios de organização" típicos de sociedades da Antiguidade e suas formas econômicas}

Depois da investigação sobre as características econômicas e os problemas da economia capitalista na Antiguidade, Weber se volta uma vez mais, na 
última parte da introdução às "Relações agrárias", à questão da significação para o desenvolvimento econômico das estruturas políticas do universo dos Estados antigos. Para tanto, Weber postula ao todo sete "estágios de organização" - de modo fundamental, ou seja, como "tipo ideal” - que poderiam ser identificados por toda parte na Antiguidade, "do Sena ao Eufrates", e que também formassem o enquadramento político do desenvolvimento econômico da Antiguidade, pelo menos em todas as partes onde tivessem se originado cidades (cf. Idem, pp. 35-42).

Aqui só se podem indicar os aspectos mais importantes das reflexões de Weber, sem tratar das inúmeras "minudências" - restrições, acautelamentos e casos excepcionais - a que ele costuma remeter (como reiteradamente é o caso). Em particular, os sete "estágios" da Antiguidade e os conceitos empregados por Max Weber referem-se a: 1) "comunidades camponesas", 2) "reinado de burgos", 3) "pólis da nobreza”, 4) “reinado citadino burocrático", 5) "Estado litúrgico autoritário", 6) "pólis dos hoplitas" e 7) "pólis democrática dos cidadãos". Essa sequência caracteriza-se sobretudo por ter ocorrido uma divisão em duas grandes direções no estágio 2 desse desenvolvimento, durante o reinado de burgos, de tal modo que dele derivou, em primeiro lugar, o reinado citadino burocrático (4), e então o Estado litúrgico autoritário (5); ou, em segundo, o reinado de burgos conduziu à pólis democrática dos cidadãos (7), passando pelos dois "estágios" da pólis da nobreza (3) e da pólis dos hoplitas (6). Se o desenvolvimento a partir do estágio do reinado de burgos levou ao reinado citadino burocrático ou à pólis da nobreza (e com isso abriu também caminho em direção ao capitalismo), dependeu fundamentalmente, segundo Weber, no primeiro caso, de o rei do burgo conquistar a supremacia sobre seu séquito e ter formado a partir dele uma administração burocrática e um exército que lhe fossem submissos, ou, no segundo caso, de seu séquito emancipar-se do rei do burgo e chegar ao poder em uma "pólis da nobreza" ou "de dinastias", sem administração burocrática (como no caso do "reinado citadino") (cf. Idem, p. 37).

A que resultado o desenvolvimento do reinado de burgos conduziu dependeu, segundo Weber, "de condições complicadas, em parte geográficas, em parte puramente históricas", algo que não há como tratar aqui de maneira detalhada. Não é difícil, porém, reconhecer que com essa "cisão" tem-se em mente o desenvolvimento geral e claramente distinto das estruturas políticas básicas no Oriente e no Ocidente na Antiguidade, onde grosso modo se defrontavam (e, por certo, durante o tempo todo desde o reinado de burgos até a Antiguidade tardia) um desenvolvimento monárquico e um 
33. No capítulo sobre a Grécia, Weber aponta expressamente para o fato de que ali o manejo de águas não teria demandado qualquer burocracia (cf. Weber, 1988, p. 94) desenvolvimento "republicano"; ou seja, de um lado, na área das "culturas das costas fluviais" do Nilo e do Tigre e Eufrates, grandes monarquias e monarquias menores; de outro, declaradamente como "cultura costeira" na região do Mediterrâneo, as cidades-estado (ou poleis), sobretudo do mundo grego e romano. Portanto, sintetizando e expressando de modo categórico: "súditos" no Oriente e, ao menos nos limites temporais mencionados, "cidadãos livres" na região mediterrânea.

Weber atribui o fato de o reinado na Mesopotâmia e no Egito, em clara oposição à região mediterrânea, haver ganhado uma posição tão predominante, entre outros fatores, à necessidade da "regulação da água" e da construção de canais a partir dos grandes rios, o que teria propiciado naquelas regióes a origem de uma administração burocrática forte ${ }^{33}$. Ao mesmo tempo, Weber constata uma diferença essencial no desenvolvimento das estruturas econômicas na Mesopotâmia e no Egito. No Egito, onde dominava um único "oikos real gigantesco", que ademais não permitia qualquer circulação econômica relevante, formara-se já no Antigo Império um "Estado litúrgico" destacado, em que cada um permanecia vinculado à sua função e, portanto, "em princípio", não era livre. Na Babilônia, ao contrário, com seu caráter mais marcadamente citadino, teriam se desenvolvido "fenômenos de circulação" muito mais fortemente do que no Egito, onde, ainda no Novo Império, o oikos real funcionara "em princípio" como uma economia natural. Sobretudo na Babilônia, ao lado dos oikoi reais, já haveria se desenvolvido desde cedo uma circulação de bens "em princípio" livre, com uma economia monetária e formas de negócio como a "comenda" (portanto, a associação de várias pessoas físicas em uma única empresa de economia aquisitiva) como um empreendimento capitalista (descontínuo), uma circulação nas prebendas oficiais, "fenômenos de circulação complexos" e, "desde o início", formas econômicas capitalistas (cf. Idem, pp. 38 ss.).

O Egito, ao contrário, segundo Max Weber, jamais conheceu algo como um "capitalismo" de verdade, nem mesmo mais tarde, no helenismo sob os Ptolomeus ou, no final, sob o domínio romano. Foi, para Weber, a monarquia helenista mais altamente desenvolvida, o "Estado modelo do helenismo" (Idem, p. 166), o "Estado helenista organizado do modo mais racional" (Idem, pp. 166 e 185). A administração era contudo "puramente burocrática"; a isso se somou o princípio litúrgico, ou seja, o vínculo inquebrantável que mantinham com suas respectivas funções aqueles que tinham obrigações com o Estado. Embora a economia monetária tenha feito alguns avanços sob os Ptolomeus, o suprimento estatal de demandas monetárias fomentou a interrup- 
ção da circulação, que se manifestou nos monopólios estatais e nas liturgias. Mesmo um elemento tão característico do capitalismo antigo como a empresa escravagista agrícola ou industrial praticamente não tinha importância no Egito (cf. Idem, p. 179). Em suma, o capitalismo foi esmagado no Egito pela forte limitação da margem de jogo para o lucro privado, sobretudo pela economia financeira estatal e as inúmeras regulamentações; e se o Egito se constituiu no Estado mais racionalizado de toda a Antiguidade, ele foi, segundo Weber, "do ponto de vista econômico e social completamente outra coisa que moderno" (Idem, p. 185).

O Egito, resume Weber em outra passagem, teria criado "duas instituições de uma perfeição jamais atingida de novo": o Estado litúrgico, com o aprisionamento da propriedade do indivíduo em sua função estatal, e a administração burocrática. A partir dali, as duas teriam conquistado o mundo antigo no final da Antiguidade, à diferença da Babilônia, onde as "formas privadas de empreendimento e as formas de valorização do capital" como que se sentiram em casa (cf. Idem, p. 83).

Não é possível aqui adentrar em uma análise individual dos diversos estágios, descritos por Weber com grande riqueza de detalhes. Mas algumas constataçôes parecem ser especialmente importantes. Em primeiro lugar é preciso evidenciar, para maior clareza, que o conceito "capitalismo" ou "capitalista" só aparece uma única vez ao longo de toda a exposição dos sete "estágios de organização" da Antiguidade, a saber - e isso dificilmente é um acaso -, no estágio da "pólis democrática dos cidadãos” (e com isso, uma vez mais, justamente nas épocas "clássicas" da Antiguidade, sempre mencionadas por Weber nesse contexto $\left.{ }^{34}\right)$. Ademais cabe registrar, no que diz respeito aos estágios de organização da Antiguidade, que toda a terceira versão de "Relações agrárias" está completamente estruturada sobre a concepção desses estágios.

A indicação do próprio Weber de que os "constituintes" de sua "teoria dos sete estágios" fossem de natureza puramente militar (cf. Idem, p. 44) ) é $^{35}$ acertada, na medida em que, de fato, não pode restar dúvida quanto ao significado fundamental do elemento militar em todos os estágios. Não obstante as características sociais, políticas e econômicas singulares, já na "comunidade camponesa" são estabelecidos nexos entre a primeira formação de chefes e de parentelas de chefes e as ameaças e capacidades guerreiras; da mesma forma, a posição do "rei do burgo" está diretamente vinculada às investidas de guerra e saque, empreendidas por ele à frente de seu séquito. $\mathrm{O}$ estágio seguinte da "pólis da nobreza" nas regiões costeiras mediterrâneas baseou-se em uma camada de "linhagens" militarmente "treinadas para o manejo profissional
34. Ver supra.

35. Com uma breve indicação do papel dos "poderes teocráticos", que em parte perpassavam os diferentes estágios. 
36. Weber trata detalhadamente do tipo e da importância do trabalho escravo, sobretudo no artesanato da Atenas "clássica" dos séculos v e IV a.C., no capítulo sobre a Grécia (Weber, 1988, especialmente pp. 139-146). Em contrapartida, sobre a economia natural espartana e a luta de Esparta - a longo prazo inócua contra sua superação monetária, ver Weber (1988, sobretudo pp. 111-113).

37. Ver supra. de armas", ao passo que o "reinado de autoridade" do Oriente, que fundamentava a outra sequência de estágios, repousava sobre o exército do rei e uma administração "burocrática”. Tratava-se de um "estágio de organização" que, segundo Weber, desenvolveu-se "sem rupturas" e "tão somente por meio [...] da organização mais racional" até o último estágio, o "Estado litúrgico autoritário". A "racionalização crescente" no suprimento da demanda desse "estágio final" em particular teve como consequência que os "súditos" fossem tratados como "meros objetos" (Idem, pp. 38, 39, 40).

Foram bem outros, no entanto, os "constituintes militares" dos dois estágios que se seguiram à "pólis das linhagens". Assim, a "pólis dos hoplitas", que surgiu depois da quebra da dominação das "linhagens", significou a transição para um exército de cidadãos que se equipavam a si mesmos e para o campesinato livre (possuidor de animais de tração) como núcleo da pólis, ou da comunidade. Aqui se fez valer um processo de "democratização" progressivo de modo completamente distinto do reinado citadino e do "Estado litúrgico". Assim, a obrigação militar aparece "relativamente democratizada" já no estágio da "pólis dos hoplitas", em contraposição à pólis de linhagens, enquanto a "pólis democrática de cidadãos", originada da pólis dos hoplitas, é caracterizada militarmente pela emancipação da obrigação militar e, com isso, pela emancipação do direito civil pleno em relação à propriedade fundiária, bem como, relacionada a isso, a admissão de todos os cidadãos aos postos oficiais. Ao mesmo tempo, segundo Max Weber, teve início aqui o desenvolvimento "capitalista", com a transição da escravidão por dívida para a escravidão por compra, que teria determinado - com a sua influência sobre as relações de posse da terra e sobre as relações industriais - a história agrária das épocas "clássicas"36.

Em termos práticos, o "capitalismo" fomentou na Grécia, de modo semelhante a Roma, uma diminuição da população livre possuidora de terras, assim como o avanço de escravos e pequenos arrendatários na agricultura. Foram deslocamentos que corresponderam militarmente à transição para um exército de "soldados" (que recebiam "soldo") ou um "exército cesarista de proletários" (em Roma). Isso significava que, da mesma forma como o Estado litúrgico representava o fim de uma série de estágios organizacionais cujo ponto de partida havia sido o Oriente, a "pólis democrática de cidadãos" representava o fim da outra série, "mediterrânea”, de estágios organizacionais, que compreendia, ao lado das "eras clássicas de florescimento" da cultura antiga, também a época principal do capitalismo na economia do mundo antigo. Essa simultaneidade ${ }^{37}$, reiteradamente destacada por Weber tem a 
ver por certo com o fato de que, a despeito da formulação grosseira, a ampla "liberdade" da economia aquisitiva capitalista na "pólis democrática de cidadãos" - seja no mundo grego, seja no romano, em oposição aos sistemas econômicos monárquico-burocráticos sobretudo do Oriente - apresentava certa analogia estrutural com a liberdade política dos agrupamentos burgueses das cidades-estado.

Para o desenvolvimento total posterior na Antiguidade decerto foi decisivo ter-se chegado ao término da série dos estágios organizacionais que antes haviam conduzido até a pólis democrática de cidadãos, devido ao surgimento em especial das grandes monarquias helenistas com Alexandre Magno e a subsequente conquista do mundo mediterrâneo por Roma, com a transformação de seu campo de poder em uma monarquia com todos os traços das que havia na Antiguidade. Assim, o "Estado litúrgico", na forma do Império romano tardio como o último "estágio organizacional" da Antiguidade, permaneceu como a forma econômica triunfante diante de todos os estágios anteriores da Antiguidade e também diante do "capitalismo" antigo ${ }^{38}$.

\section{O capitalismo da Antiguidade e seu fim}

Para terminar, cabe ao menos esboçar brevemente como o capitalismo na Antiguidade chegou ao fim. Weber tratou desse processo, com riqueza de detalhes, no capítulo final de "Relações agrárias" de 1908, intitulado "Fundamentos do desenvolvimento na época imperial" (cf. Idem, pp. 254-277). O ponto de partida, para Max Weber, é o desenvolvimento das cidades ou cidades-estado, cuja expansão prosseguiu ainda até o século III d.C. (cf. Idem, pp. 253 ss.). Com a finalidade de determinar mais precisamente a sua estrutura e melhor esclarecer a questão dos limites do desenvolvimento do capitalismo antigo, Weber recorre a uma comparação detalhada com a "cidade da Idade Média" como uma das raízes mais importantes do capitalismo moderno (cf. Idem, pp. 254-271). Ao fazê-lo, acentua especialmente as enormes diferenças políticas e militares entre os dois tipos de cidade. A cidade antiga, afirma Weber, teria sido a "organização militar mais perfeita produzida pela Antiguidade" (cf. Idem, p. 262) e em tal medida adequada para conquistas (como bem indica a expansão de suas estruturas sobre praticamente toda a regiāo do Mediterrâneo, ao longo da Antiguidade). Esses traços guerreiros, por outro lado, faltam à cidade medieval, que por exemplo não conhecia camponeses sem-terra como uma força de expansão da política citadina (cf. Idem, ibidem). Assim
38. A esse respeito, ver infra. 
39. Sobre o caráter capitalista, em especial da expansão romana ultramarina, ver Weber (1988, pp. 234-236).
Weber caracteriza, também de forma marcante, o aspecto geral da antiga “pólis de cidadãos” (democrática):

Desde o início, e sempre que se lhe ofereciam chances, ela foi guerreira, conquistadora, sempre à procura de monopólios de comércio, de súditos pagadores de tributos, de terras para provimento das gerações vindouras de hoplitas, ou então à procura de ocasiōes para multiplicar as rendas dos pequeno-burgueses; e fixou-se sempre e por toda parte onde um poder político mais forte não impediu a sua sanha de alcançar tudo o que estivesse ao seu redor (Idem, p. 267) ${ }^{39}$.

Reiteradamente Weber enfatizava o quanto o capitalismo antigo dependia, como um dos principais pressupostos de sua existência, de guerras bem-sucedidas para o suprimento constante dos mercados de escravos (cf. Idem, pp. 19, 25, 30).

No desenvolvimento do capitalismo antigo, o ponto de inflexão mais prenhe de consequências, segundo Weber, devia-se, desde a História agrária romana, à passagem de todo o mundo antigo à "Pax Romana", isto é, à ampla suspensão das guerras de conquista pelo Império romano, que ele data do período entre Tibério e Adriano. Ela teria conduzido necessariamente a uma atrofia das formas econômicas capitalistas existentes até então. Além disso, estaria ligada a outras transformaçôes de longo prazo e de grande profundidade (cf. Idem, pp. 271 ss.). Durante o tempo de paz, a cultura antiga avançou de seu centro de gravidade até então, as regiōes costeiras do Mediterrâneo, interior adentro, onde a expansão da circulação econômica teria deparado contudo com dificuldades consideráveis, já que lá, havia muito tempo, predominavam as "dominaçōes fundiárias", ou seja, um tipo de economia do oikos com tendência a autarquia (como ocorria em geral na Antiguidade fora das grandes regiōes costeiras ou das margens dos rios). Isso resultou na desvinculação do mercado das cidades situadas nos territórios interiores, no declínio de sua importância e em um retrocesso dos interesses capitalistas e das possibilidades de lucro (cf. Idem, p. 273). Outro momento decisivo para esse deslocamento do centro de gravidade da cultura antiga teria sido o novo caráter monárquico de Roma como potência mundial, que teve início com o Império. A “administração da pólis”, ou a administração precedente (não burocrática) da República, havia se revelado agora "totalmente insuficiente" para um império mundial, e uma série de fatores (entre eles o "colapso da antiga economia monetária”) acabou provocando desde o século II d.C. aproximadamente a passagem do do estágio da "pólis 
de cidadãos" ao estágio do "Estado litúrgico" (ou, na expressão latina, do Estado de "munera”), em relação ao que Weber enumera toda uma série de sintomas (cf. Idem, p. 275). Ao mesmo tempo, o Estado antigo teria sufocado o capitalismo na "rede" do Estado litúrgico, de maneira "lenta mas segura", pois sem dúvida alguma era incompatível com ele (cf. Idem, ibidem ${ }^{40}$. Weber pergunta por que os tempos de paz do Império (ele tinha em mente os séculos I, II e IV d.C.) não teriam sido também épocas de florescimento da economia capitalista e responde essa questão com o argumento de que o capitalismo antigo teria sido "ancorado politicamente" e a formação de capital, conforme já se constatou diversas vezes, estaria fundamentalmente vinculada à "exploração privada" da dominação política, em uma cidadeestado expansiva e em constante atividade guerreira (cf. Idem, p. 276) ${ }^{41}$. Tudo isso retrocedeu cada vez mais. Ao mesmo tempo, todo o sistema tributário foi progressivamente estatizado e a arbitrariedade dos arrendatários de impostos, combatida. Em síntese, segundo a formulação de Weber: "O Império lançou o capitalismo em uma situação orçamentária mortal" (Idem, ibidem). Mas não apenas o "sufocamento" da economia aquisitiva capitalista privada ocasionaria o declínio do Império romano. Seria mais correto dizer que, diante da impossibilidade de uma expansão militar continuada, não restou ao Império outra opção, uma vez concluídas as conquistas militares, senão eliminar por completo o capitalismo e deixar que Roma e seu Império se tornassem um amplo Estado litúrgico "segundo o modelo helenista-egípcio" (Idem, p. 275). Tampouco esse Estado logrou impedir o fim da metade ocidental do Império romano no século $\mathrm{V}$, sobretudo em consequência das grandes migrações.

Ao final de toda sua confrontação perspicaz com o problema do capitalismo na Antiguidade, Weber ainda lança, repentinamente, uma ponte com o futuro do capitalismo atual (cf. Idem, pp. 277 ss.), declarando expressamente que também este, "com toda probabilidade, em algum momento" (Idem, p. 278) sucumbirá à burocratização da economia por meio de uma ordem - ideal-típica - semelhante à do "Estado litúrgico" do período tardio da era imperial romana e, ainda mais, do Novo Império egípcio ou da era ptolomaica, com um atrelamento burocrático do indivíduo "a um fundamento apenas tecnicamente completo", ainda que o "continuum do desenvolvimento cultural mediterrâneo europeu" até o momento não possibilite predições seguras (cf. Idem, ibidem).

Mais tarde, em Wirtschaft und Gesellschaft [Economia e sociedade], Weber apontou o fato de que também no passado as possibilidades da orientação 
capitalista para a aquisição teriam "encolhido" nos locais em que grandes porções de terra foram pacificadas (reinos unificados: China, Roma tardia) (cf. Weber, 1921e, p. 96). Na Wirtschaftsgeschichte [História econômica] de 1919-1920, Max Weber reiterou esse pensamento no mesmo contexto e esclareceu que na Época Moderna seria o "Estado nacional fechado" e com fronteiras que garantiria a continuidade do capitalismo. O texto termina nesse ponto com a frase: "Enquanto ele [isto é, o Estado nacional] não der lugar a um império mundial, também o capitalismo perdurará" (MWG III/6, p. 369).

Não resta dúvida: se Max Weber tem razão com essa profecia, então o capitalismo "moderno" ainda tem uma longa vida pela frente.

\section{Sinopse}

Houve também na Antiguidade algo como "capitalismo", considerado a forma econômica mais importante e exitosa da Época Moderna? Por volta da virada do século XIX para o XX, sobretudo duas posições contrapunham-se com certa nitidez diante dessa questão. Segundo uma dessas concepções, estabelecida por Johann Karl Rodbertus e revitalizada por Karl Bücher, a Antiguidade foi economicamente dominada, no essencial, pela "economia doméstica fechada", constituída pelos integrantes livres e cativos da "casa" (grego, oikos). Nela, atribuía-se apenas um papel secundário à circulação econômica, ou seja, ao comércio, e com isso também à economia aquisitiva. Quem se opôs mais decididamente a essa concepção foi Eduard Meyer, para então defender a declarada "modernidade" da Antiguidade também no aspecto econômico. Max Weber, que já em sua História agrária romana, de 1891, havia falado diversas vezes de "capital" e "capitalismo" em Roma, ainda que sem fundamentação explícita, viu-se motivado a uma tomada de posição própria e aprofundada ante a questão na terceira e última versão de seu grande verbete "Relações agrárias na Antiguidade" (1908). Chegou à conclusão de que o "capitalismo" - entendido sempre como emprego de objetos de posse (entre os quais se incluíam neste caso em especial os escravos) na circulação econômica com a finalidade de ganho - de fato desempenhara um papel essencial em determinadas épocas da Antiguidade.

Entre as marcas estruturais desse capitalismo antigo, que Weber apresenta com grande riqueza de detalhes, incluem-se - ao lado da ausência de todos os meios técnicos modernos, assim como da grande empresa (um dos principais alicerces do capitalismo da Época Moderna) - um grande número 
de riscos associados ao capital de escravaria e, ligado diretamente a isso, o problema permanente da reposição, o que conduzia a guerras regulares de conquista e de captura de seres humanos. Ao mesmo tempo, no entanto, o auge do capitalismo antigo deu-se nas "épocas clássicas de florescimento" da Antiguidade, ou seja, sobretudo a Grécia dos séculos v e IV a.C., assim como a Roma da época republicana (especialmente da fase tardia).

Nesse sentido, Weber desenvolve vários modelos, em parte geográficos, em parte econômicos e políticos, especialmente o da cultura às margens dos grandes rios, o da cultura costeira e o da cultura no interior do continente, desde o Oriente antigo, passando pela Antiguidade mediterrânea, até alcançar o Império romano tardio, assim como uma sequência de determinados "estágios de organização" do mundo citadino mediterrâneo e oriental, que conduzira sobretudo no Oriente à monarquia litúrgica, algemando o indivíduo e seu patrimônio ao Estado, enquanto no âmbito das cidades-estado mediterrâneas, por outro lado, conduzira à "pólis democrática de cidadãos".

Um desenvolvimento pleno do capitalismo antigo, ainda que se possa em parte remontar sua origem à Babilônia, ocorreu essencialmente, segundo Weber, no estágio da "pólis democrática de cidadãos", aquele período no mundo greco-romano de liberdade política e, ao mesmo tempo, de economia aquisitiva privada do cidadão, que se considera tradicionalmente como o auge do desenvolvimento cultural da Antiguidade. Ao final, contudo, acabou por prevalecer na Antiguidade o Estado litúrgico burocrático (segundo a terminologia weberiana) como vencedor sobre o capitalismo e sua liberdade econômica. Entre os fatores mais importantes, reiteradamente investigados por Weber, que contribuíram decisivamente para esse resultado, estava sobretudo o término das diversas guerras de conquista, que pôs gradualmente um fim à reposição do capital de escravaria. Além disso, também a impossibilidade de transpor as formas econômicas capitalistas desenvolvidas até então na "cultura costeira" aos vastos territórios do interior do continente conquistados por Roma. Em vez disso, desenvolveu-se ali, com as "dominaçôes fundiárias" que tendencialmente se desvinculavam do mercado citadino, uma nova "economia de oikoi", por meio da qual a administração burocrática do império mundial, com seus meios de vinculação do patrimônio ao Estado (que remontavam ao Egito e ao Oriente), tentava dar suporte a este último. Com isso, porém, o capitalismo da Antiguidade extinguiu-se como que completamente, e só muito mais tarde, após o fim do império mundial romano, é que surgiria, sobre bases modificadas, um novo capitalismo: o capitalismo "moderno" do Ocidente. 


\section{Resumo}

A teoria econômica dos Estados antigos: a questão do capitalismo na Antiguidade na visão de Weber

$\mathrm{O}$ artigo discute o problema do capitalismo na Antiguidade, tal como Max Weber o formulou. Trata, portanto, de reconstruir o entendimento de Weber desse fenômeno, ou seja, das formas de organização econômica na Antiguidade. A análise do texto de Weber de 1908, "Agrarverhältnissen im Altertum” [Relações agrárias na Antiguidade], oferece a base de toda a discussão; mas também são abordados o contexto intelectual da problematização de Weber, como a polêmica Meyer-Bücher acerca dos fundamentos da economia antiga, assim como aspectos específicos do capitalismo antigo, no entender de Weber, em que a relação com a dimensão política ocupa papel de destaque. Palavras-chave: Max Weber; Max Weber Gesamtausgabe; Antiguidade; Capitalismo; Economia; História; Sociologia.

\section{Abstract}

Economic theory of the ancient States: Weber's view of the question of capitalism in Antiquity

The article discusses the problem of capitalism in Antiquity, as formulated by Max Weber. It seeks to reconstruct Weber's understanding of the phenomenon, that is, the forms of economic organization in Antiquity. An analysis of Weber's 1908 text "Agrarverhältnissen im Altertum" [Agrarian relations in Antiquity] provides the basis for the discussion as a whole. However the article also examines the intellectual context of Weber's problematization, such as the Meyer-Bücher polemic concerning the fundamental aspects of the ancient economy, as well as specific aspects of ancient capitalism, as Weber understood them, where the relation with the political dimension assumes a prominent role.

Keywords: Max Weber; Max Weber Gesamtausgabe; Antiquity; Capitalism; Economics; History; Sociology. 